\title{
The innovative activity in depressed regions of the Russian Federation
}

\author{
Marina Palkina ${ }^{1, *}$, Nadezhda Matveeva $^{2}$, and Nadezhda Psareva $^{3}$ \\ ${ }^{1}$ Vyatka State University, 36, Moskovskaya str., 610000, Kirov, Russia \\ ${ }^{2}$ State University of Management, 99, Ryazansky Prospekt, 109542, Moscow, Russia \\ ${ }^{3}$ Educational institution of higher education trade unions "Academy of Labor and Social Relations", \\ 90, Lobachevsky str., 119454, Moscow, Russia
}

\begin{abstract}
Intensification of the innovative activity of regions in modern conditions is a strategic factor in the growth of their economies. Practice shows that those regions in the economy of which the change of traditional technologies to innovative ones took place timely demonstrated a high level of socio-economic development. In this connection, the innovative activity acquires special relevance in depressed regions, where the dynamics of indicators of socio-economic development is significantly lower than the average in the country. The lack of analytical information on the state, general trends and features of the development of the innovative activity in such problematic regions makes it necessary to conduct such studies, which made the authors choose the topic of the article. The purpose of this article is to identify trends and characteristics of the development of the innovative activity in the depressed regions of the Russian Federation. The informational basis of the analysis was statistical data from open sources on the results of the innovative activity of the regions of the Russian Federation that are classified as depressed [17]: the Volgograd Region; the Ivanovo region; the Kirov region; the Ulyanovsk region; the Kurgan region; the Oryol Region; the Smolensk region; the Pskov region; the Chuvash Republic; the Altai Territory. The study is based on the complex and systematic approaches with the use of economic-statistical, logical and expert analysis methods. As a result, the authors concluded about the insufficient level, differentiated nature of the dynamics, and significant interregional differences in the values of the indicators of the development of the innovative activity in the studied regions. The results of the study can be used by authorities when choosing the innovative strategy and methods of state support for innovative activities in depressed regions in order to transfer their economies from the current state.
\end{abstract}

\section{Introduction}

As a result of market reforms, the differentiation of the regions in the Russian Federation intensified, as a result of which a large number of Russian regions were

\footnotetext{
*Corresponding author: palmavik@yandex.ru
} 
considered depressive by the beginning of the 21 st century [8]. Therefore, the researches and developments devoted to the analysis of the features of the depressed regions and the formation of mechanisms to get them out of the current state are relevant and promising.

The very first mention of "depression" in relation to the regions was recorded in 1995 in the Decree of the Government of the Russian Federation "On the Program of the Government of the Russian Federation "Reforms and Development of the Russian Economy in 1995 - 1997", according to which the depressed region is "a territory with sufficient economic potential, but as a result of a structural crisis characterized by a steady decline in production and real incomes of the population, growing unemployment. "

Later, in the draft Federal Law "On the Fundamentals of Federal Support for Depressed Territories of the Russian Federation", adopted in the second reading on March 12, 2003, a more precise definition of the concept of the depressed territory was formulated - this is "an administrative unit (district, city) or a set of adjacent administrative units within the boundaries of one or more constituent entities of the Russian Federation, having a homogeneous economic structure, which, as a result of an acute crisis in the main sector(s) of the economy is in extreme economic decline. In the third reading the draft law clarified the definition of the depressed territory: the main sector of the economy is a branch of industry, construction, transport, communications, trade and (or) agriculture, which employed at least 25 percent of working-age population of the given territory or which share in the gross regional product is at least 30 percent over the past 12 years.

The analysis of approaches to the interpretation of the concept of the depressed region in the scientific literature revealed a lack of unity of opinion and clear definitions of this definition. So, for example, Shtulberg B.M. gives the following interpretation of the depressed region: "territories with a relatively high level of previously accumulated economic potential, a significant share of industrial production (mainly manufacturing sectors) in the structure of the economy, a relatively high level of skills of local labor resources, but having faster rates of economic decline in the core industries, higher unemployment rate, low investment activity, low levels of budgetary security and real incomes of the population compared with the country averages" [10].

V.E. Seliverstov, M.K. Bandman and S.S. Guzner believe that depressed regions were very developed regions in the past, but for various reasons they have now lost their leading positions [11].

According to Yakovenko N.V. depressed regions are a special (sometimes numerically expanding, sometimes relatively small) typological group with the following characteristic features: a deep and intense decline at the crisis stage of cyclical rhythm and a slow (delayed) entry into the growth phase, increased socio-economic instability [12].

Another author, Asmus O.V., defines depressed regions as "subjects of the Russian Federation which have human, infrastructural, climatic, scientific and technical potential, but dynamics (at least 5 years) of growth rates of the main indicators of socio-economic development, including integrated, is lower than the national average, or the established standard" [13]. The scientist offers the following indicators for identifying depressed regions: per capita GRP and budgetary security, the level of employment and investment attractiveness of the territory, indicators of the rate of increase in production and population incomes.

Surkova S.A. and Shusharina V.V. consider the depressive region as "a territory where the production and resource base has entered a phase of sustained decline, eliminating the emergence of new development incentives" [8].

Balakina G.F. suggests referring to "depressed regions" those "problematic (crisis) regions in which modern development is characterized by low economic activities, a decline in production volumes in traditional specialization sectors, crisis processes and, as a result, a decrease in the level and quality of life of the population" [16]. Such regions do not 
have their own resources to get out of the depressive state or they are not enough. At the same time, such regions, according to the author, have accumulated economic potential, a significant share of industry in the current structure of the economy, and a significant number of highly skilled workers.

Granberg A.G. in his scientific works formulated the essence of the concept "depressed region" most accurately [9]. According to Granberg A.G. regions can have a variety of problems (economic, social, etc.) and their combinations. The main types of problem regions are: depressed and backward. Depressed regions differ from the backward ones in that having the same, lower than the average Russian modern values of socio-economic indicators, in the past these regions were developed and occupied leading positions in some industries in the country. Therefore, the production potential in such regions is quite developed, the share of industrial production in the structure of the economy is significant, and the level of qualification of labor resources is high. Due to various reasons, these regions have lost their significance and advantages and have become depressed. In our opinion, this understanding of the essence and definition of this definition should be adhered to.

It should be noted that the understanding of the essence of the depressed region in foreign countries and in the Russian Federation is significantly different. This difference in understanding is due to the difference in the reasons for the appearance of such regions. The main reasons for the formation of depressed regions abroad are: imbalance in the development of various sectors of the economy and a small degree of diversification of production [14]. The main reasons for the formation of depressed regions in the Russian Federation are: denationalization, privatization, decline in production, lack of competitiveness of products, lagging behind scientific and technological progress, the emergence of new sales markets and consumers, etc., that accompanied the process of transition of the national economy to the market [15].

Depressed regions abroad have the following features: narrow structure of industry; low diversification of production; imbalance in the development of various sectors of the economy; a high share of production in the structure of the economy; geographical isolation from the centers of economic and cultural progress; poor adaptation to alternative activities; the outdated nature of social and industrial infrastructure [15].

In order to classify the region as depressed, scientists propose various criteria. In this work, the approach of Chernyshev K.A. was used for these purposes, which offers the following criteria: 1) a decrease in industrial production compared to 1991 to the level of no more than $70 \%$; 2) the volume of GRP per capita is less than $70 \%$ of the average Russian level; 3) the unemployment rate is higher than the national average; 4) the volume of industrial production per capita (a value equal to more than $30 \%$ in relation to the average level of industrial production per capita in the Russian Federation). In accordance with K.A. Chernyshev's criteria the following subjects of the Russian Federation were classified as depressed regions: the Smolensk Region; the Kirov Region; the Pskov Region; thee Ivanovo Region; the Oryol Region; the Volgograd Region; the Chuvash Republic; the Ulyanovsk Region; the Kurgan Region; the Altai Territory [17].

In modern conditions, the prospects for the innovative development of national economies are more dependent on how the innovative development of the economy will proceed in the regions themselves. The prospects for the development of the economy of depressed regions play an important role, as they pose a serious threat to the growth of regional differentiation. In this regard, state authorities at the federal and regional levels are interested in accelerating the deployment of the process of creating and introducing innovations in such regions, as this leads to increased competitiveness of local industries, filling the revenue side of regional budgets, increasing the quality of life and welfare of the population living on these territories. Therefore, the study of the state, trends and factors of 
the development of the innovative activity in depressed regions in modern conditions is of particular interest.

Various aspects of regional depression were considered in the works of such domestic scientists as: Zubarevich N.V., Leksin V.N., Shvetsov A.N., Bogacheva O.V., Kovalenko E.G., Mansurov P.M., Mansurova G. I., Kupershtokh V.L., Sokolov V.M., Suspitsyn S.A., Yagolnitser M.A. and so ont. In foreign literature, similar questions were studied by Boschma R., Lambooy J., Cumbers A., Birch K., Hassink R., Shin D., Iking B., McGahey R., Vey J., Steiner M., Tsipouri L. For example, Ron A. Boschma and Jan G. Lambooy considered the problem of developing old industrial regions in decline, based on interactive training [1]. Cumbers A. and Birch K. studied the state, experience and problems of development of old industrial regions in Western Europe [2]. Hassink, R and Shin, D. analyzed the problems of restructuring old industrial areas [3]. Steiner M., Tsipouri, L., McGahey R., Vey, J., Iking, B. also examined development of old industrial areas [4-7].

At the same time, the degree of knowledge of the innovative activity in depressed regions remains insufficient. Due to the fact that these regions increase the unevenness of the spatial, socio-economic and innovative development of the country, there is a need for such studies.

\section{Materials and Methods}

The information base for this study was the following materials: 1) statistics digests posted in the public domain on the website of the Federal State Statistics Service of Russia; 2) statistics digests and analytical reports of the National Research University Higher School of Economics, posted in the public domain on the HSE website; 3) reports on the results of the formation of the rating of the Association of Innovative Regions of Russia (AIRR), posted in the public domain on the AIRR website.

In the process of preparing this work, the following basic scientific methods were used: economic-statistical; logical; judgmental. We studied the structure and dynamics of statistical indicators of the innovative activity for the considered period of time, revealed trends in the development of the innovative activity in depressed regions using the economic and statistical methods. The use of these methods increased the accuracy of conclusions and the validity of the developments proposed in this article. Logical methods made it possible to establish causal relationships, analyze common features and identify peculiarities of the development of the innovative activity in depressed regions. Judgmental methods, comparative analysis, methods of data visualization in the form of tables and graphics were also used in this study.

\section{Results}

The analysis of the innovative activity of organizations by the value of the share of organizations that implemented innovations in the total number of organizations surveyed in depressed regions for 2010 - 2017 allowed to establish the following (Figure 1). The leading position in terms of the level of the innovative activity of organizations is held by one region - the Chuvash Republic. It should be noted that the gap between the leading region and other regions for this indicator is significant: 2.3 times higher than the average value for all depressed regions and 3.7 times higher than the average value of the regionoutsider for this indicator - the Ulyanovsk Region. In three depressed regions (the Chuvash Republic, the Altai Territory, and the Kirov Region), starting in 2015, the share of innovatively active organizations was higher than the average values calculated for both depressed regions and the Russian Federation as a whole. 
On average, in $70 \%$ of the depressed regions over the analyzed period, the proportion of innovatively active organizations in the total number of organizations was lower than the all-Russian values. The analysis of the dynamics of this indicator from 2011 to 2017 allowed us to find out a steady trend towards reducing the innovative activity of organizations in $60 \%$ of the depressed regions. In $40 \%$ of the depressed regions, the opposite trend was revealed - an increase in the share of organizations implementing innovations in the total number of organizations in the region

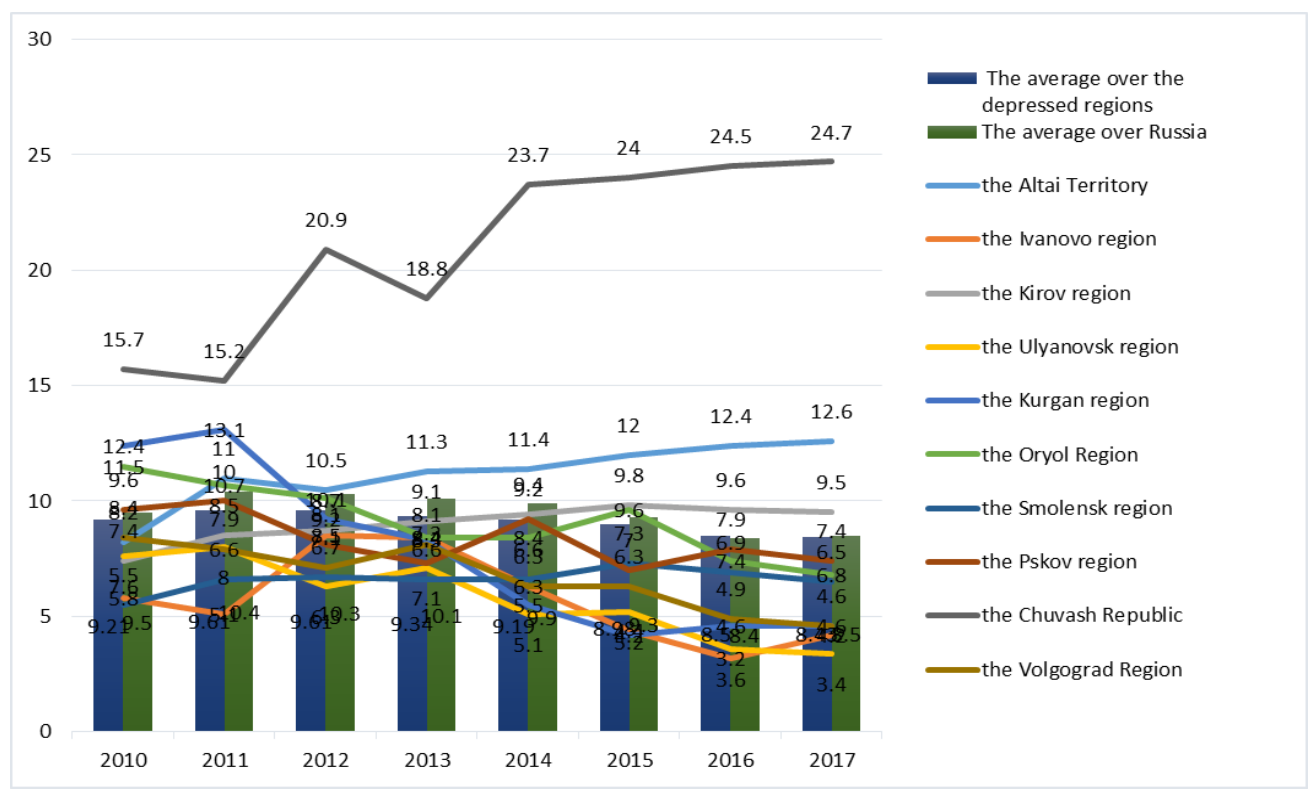

Fig. 1. The innovative activity of organizations (the proportion of organizations that implemented innovations in the total number of organizations surveyed; in percent) (Data source: Rosstat).

Taking into account these facts, we can conclude that the level of the innovative activity of organizations in the depressed regions is low (regarding all-Russian values), the differentiation and multidirectional trends in the development of innovative activities in depressed regions are high.

As a result of the analysis of the dynamics of costs for technological innovations (as a percentage of the total volume of goods shipped, work performed, services) from 2010 to 2018 (Figure 2), the following was found. 


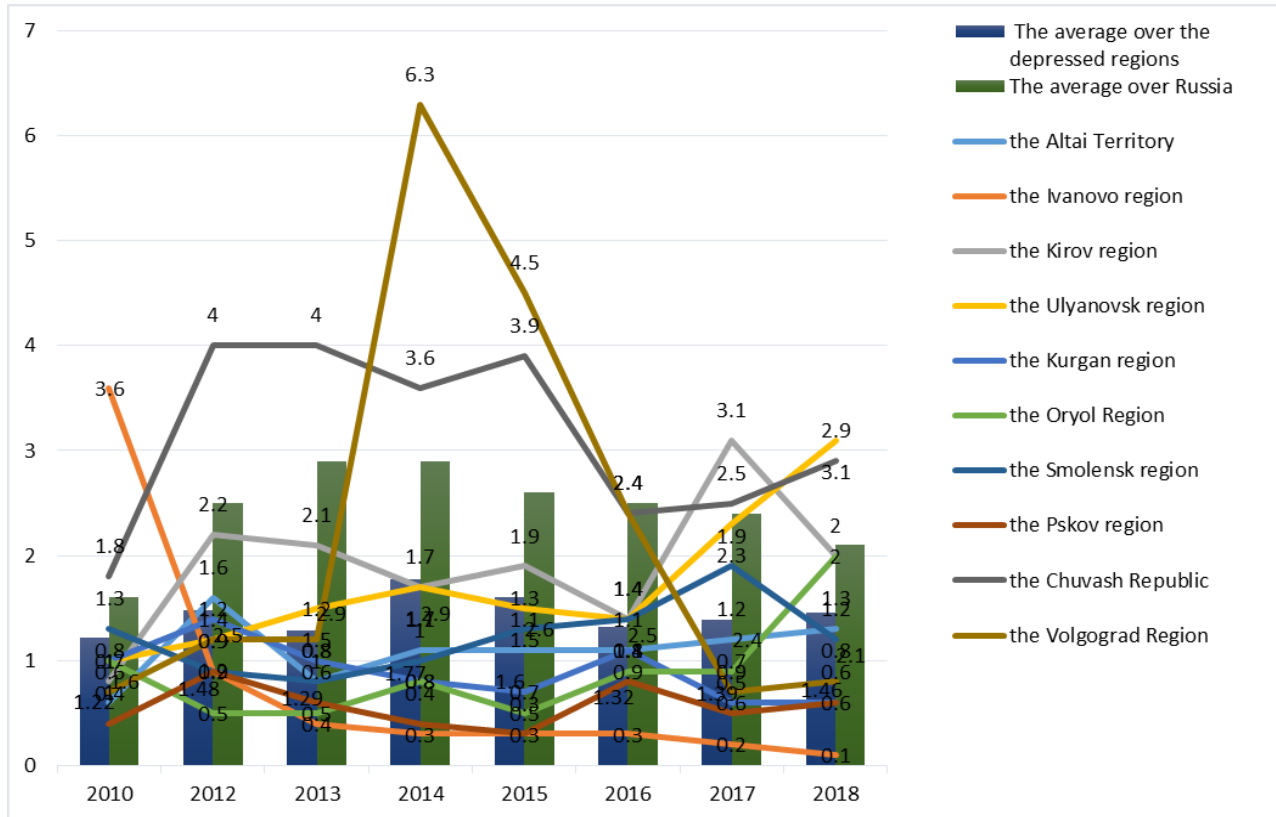

Fig. 2. Costs for technological innovation (as a percentage of the total volume of goods shipped, work performed, services) (Data source: Rosstat).

During the analyzed period, the average value of the level of costs for technological innovations in the depressed regions was lower than the average all-Russian values. The leader in the group of the depressed regions by this indicator can be considered the Chuvash Republic, which value of this indicator is almost 2.6 times higher than the average for all Russian regions, and 4.4 times higher than the average for the depressed regions. In almost $80 \%$ of the depressed regions, the level of costs for technological innovations throughout the analyzed period was lower than the average of Russia. The worst value of this indicator was recorded in one region - the Ivanovo region. In particular, the gap between the Chuvash Republic (the region that is the leader in this indicator) in the Ivanovo region amounted to more than $400 \%$.

The analysis of the dynamics of this indicator from 2012 to 2018 revealed multidirectional trends in the depressed regions: $50 \%$ of the depressed regions showed a tendency to increase the share of costs for technological innovations, 30\% showed a downward trend, $20 \%$ showed unstable shifts both in the direction of growth and in the direction of decrease.

Thus, during the analyzed period, significant regional differences were observed among the depressed regions in terms of the dynamics of the share of costs for technological innovations.

When assessing the state and trends of development of the innovative activity in the regions, an important indicator is the "Volume of innovative goods, works, services (as a percentage of the total volume of goods shipped, work performed, services)". In the process of analyzing the dynamics of the indicator for the period from 2015 to 2018 the following was revealed (Figure 3). 


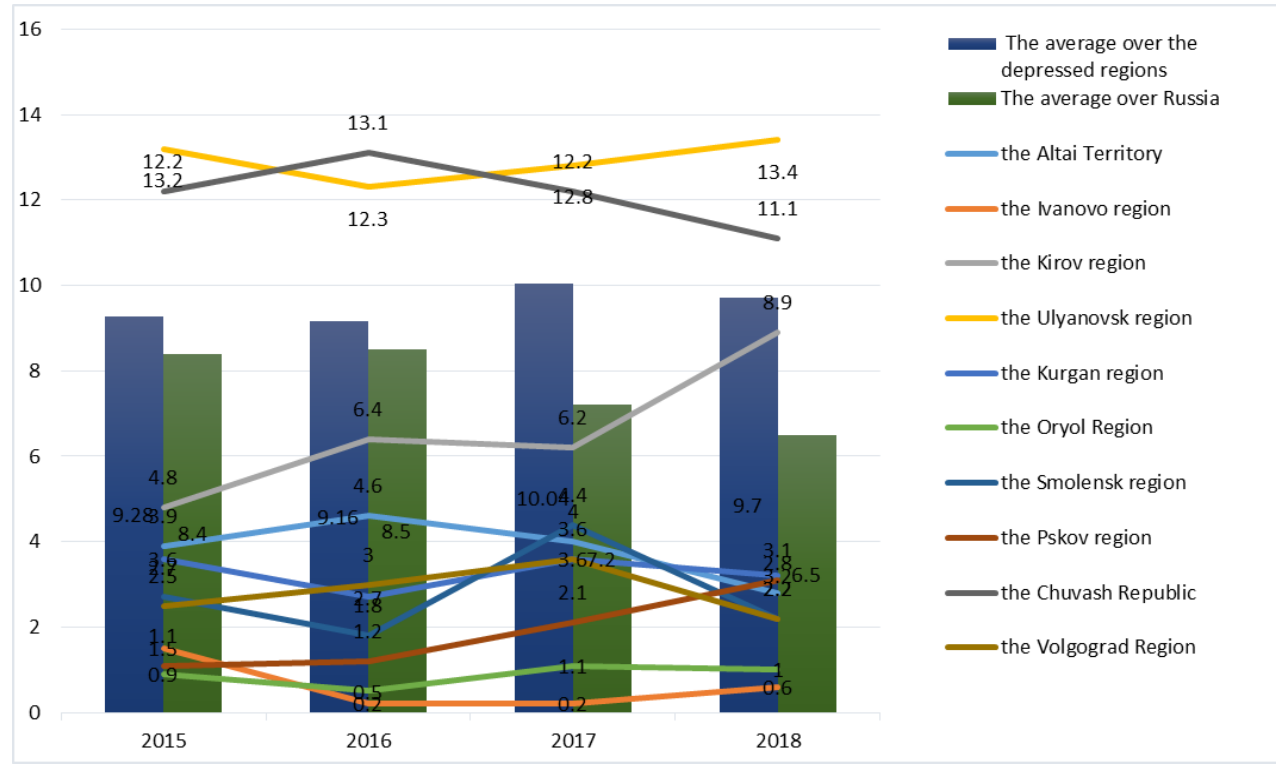

Fig. 3. Volume of innovative goods, work, and services (as a percentage of the total volume of goods shipped, work performed, services) (Data source: Rosstat).

The leading regions in this indicator are the Ulyanovsk Region and the Chuvash Republic. The gap between the leading regions and other depressed regions is significant for this indicator. In particular, the excess of the average value of this indicator of the leading regions over the value of this indicator of the region-outsider (the Ivanovo region) in 2018 was more than 20 times.

During the analyzed period, in almost $80 \%$ of the depressed regions, the share of innovative goods, works, and services in the total volume was lower than the average for all regions of the Russian Federation. It should be noted that half of the depressed regions showed a tendency to increase the volume of innovative products in the total volume of shipped products, $30 \%$ showed a downward trend, and $20 \%$ showed both an increase and a decrease.

Thus, it can be concluded that the share of innovative products is low (regarding national values) and that its dynamics is significantly uneven in the depressed regions, which correlates with the conclusions made earlier.

Another important indicator of the state of the innovative activity in the regions is "The proportion of organizations that carried out innovations of certain types in industrial production (in the total number of organizations)" (Figure 4, 5, 6). The following types of innovations are distinguished: technological, organizational and marketing. Starting from 2011, the leading positions in technological innovation have been occupied by two depressed regions - the Chuvash Republic and the Altai Territory. The gap between these regions and the region-outsider (the Ivanovo region) in terms of the average value of the indicator is almost 5 times. It should be noted that this type of innovation is the second most popular among organizations in the depressed regions. The share of organizations implementing technological innovations in the total number of organizations in $40 \%$ of the depressed regions was higher than in other Russian regions. 


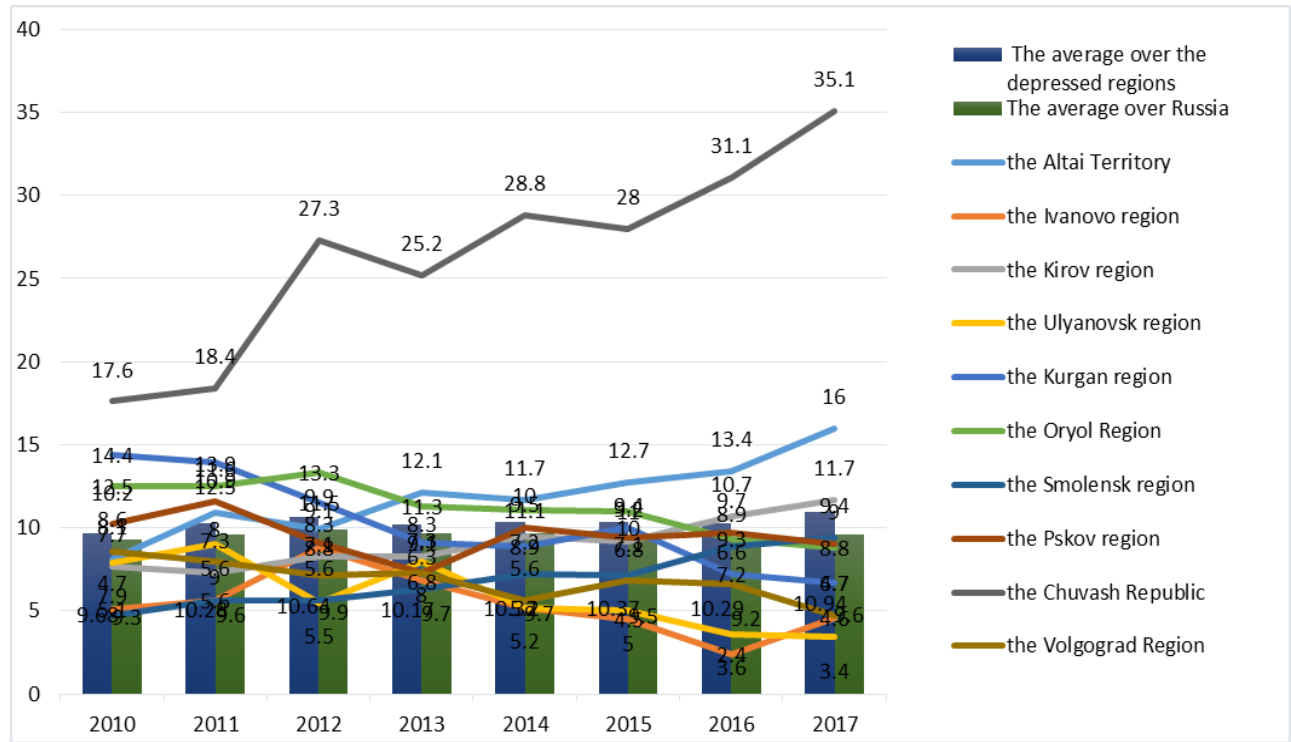

Fig. 4. The proportion of organizations that carried out technological innovations in the total number of organizations (in industrial production, in percent) (Data source: Rosstat, HSE).

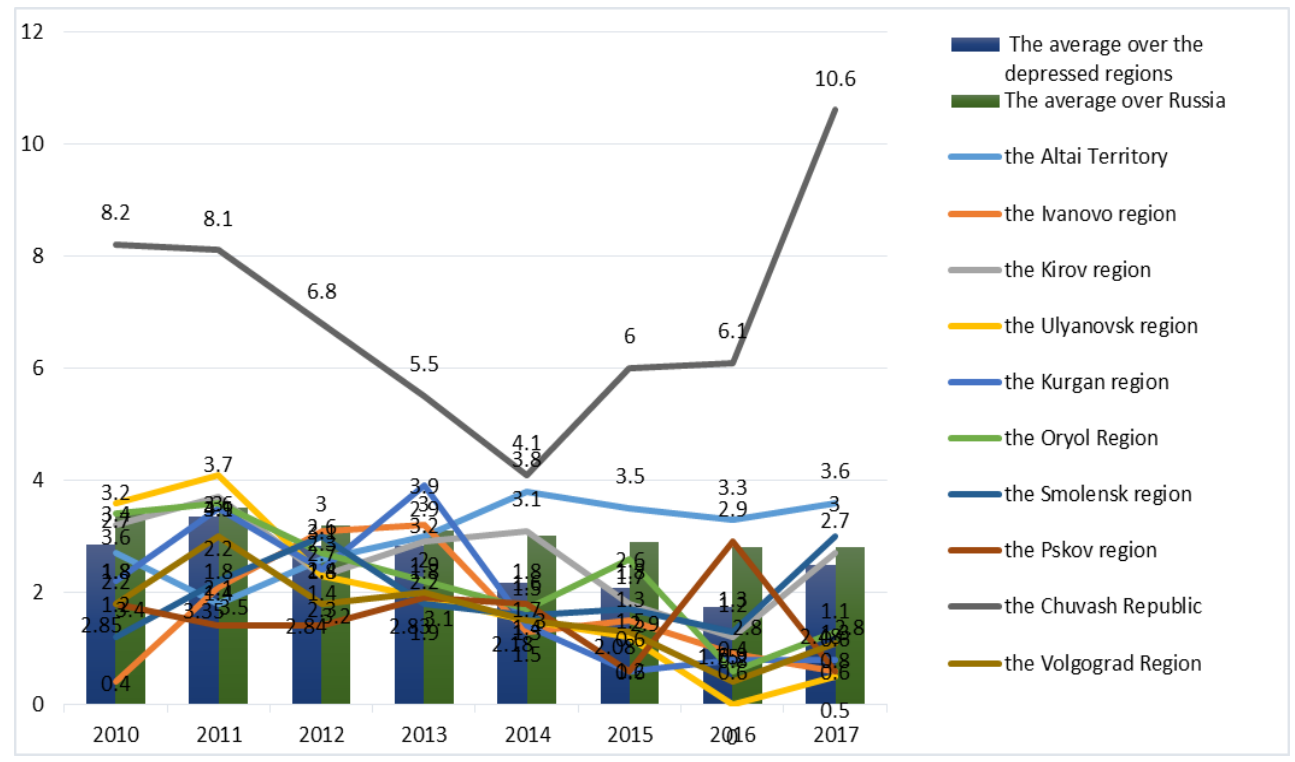




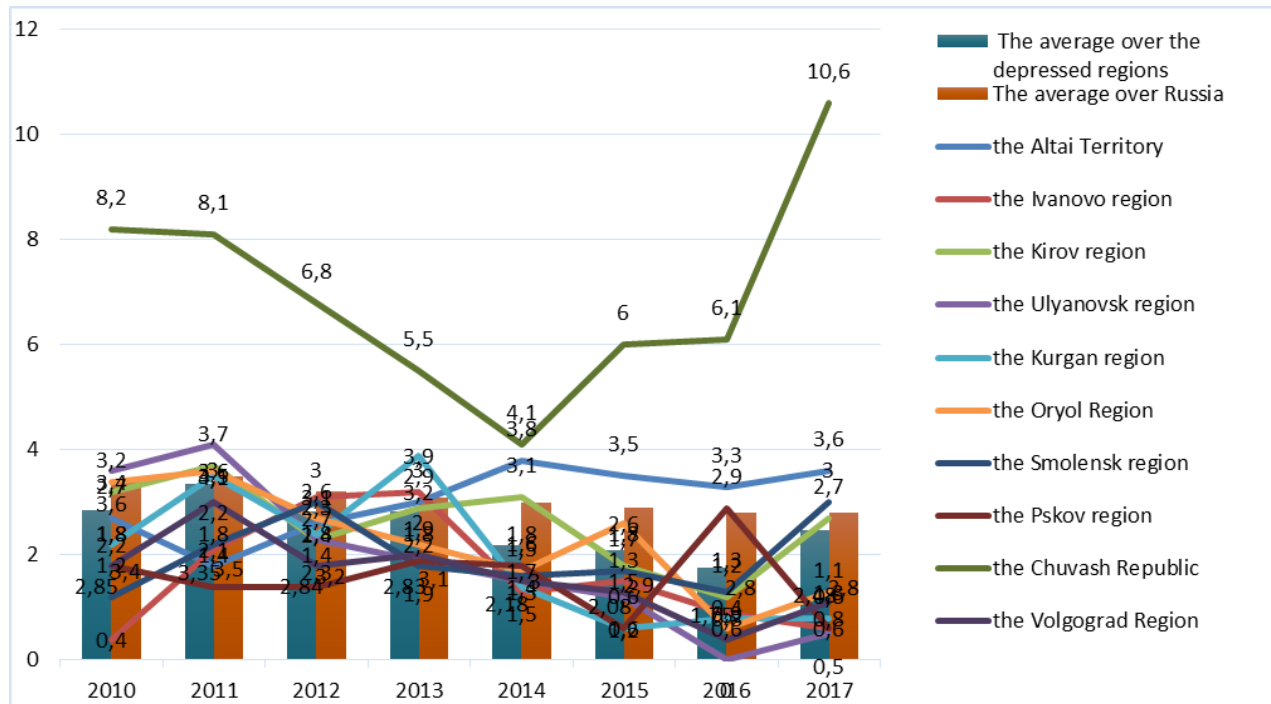

Fig. 5. The proportion of organizations implementing organizational innovations in the total number of organizations (in industrial production, in percent) (Data source: Rosstat, HSE).

Since 2014 leadership in organizational innovations has also belonged to two regions - the Chuvash Republic and the Altai Territory. The gap between the region-outsider (the Ulyanovsk region) by the average value of the indicator is almost 3 times. In $70 \%$ of the depressed regions, the share of organizations implementing organizational innovations from 2010 to 2017 was lower than the national level.

Compared to other types of innovations, marketing innovations are most actively used in the depressed regions: the share of organizations engaged in marketing innovations from 2010 to 2017 is higher than the average for Russia in almost $60 \%$ of the depressed regions. The leadership in this type of innovation belonged to the Chuvash Republic and Altai Territory. The gap between the values of the region-outsider (the Volgograd region) and these two regions is more than 5 times.

The analysis showed that in the depressed regions the share of organizations implementing technological innovations is dominant. This coincides with the all-Russian trend. At the same time, marketing innovations in the depressed regions are being introduced in more organizations than the average for the Russian Federation. Also, during the analysis it was found that in the depressed regions there is a significant unevenness in the introduction of all types of innovations. 


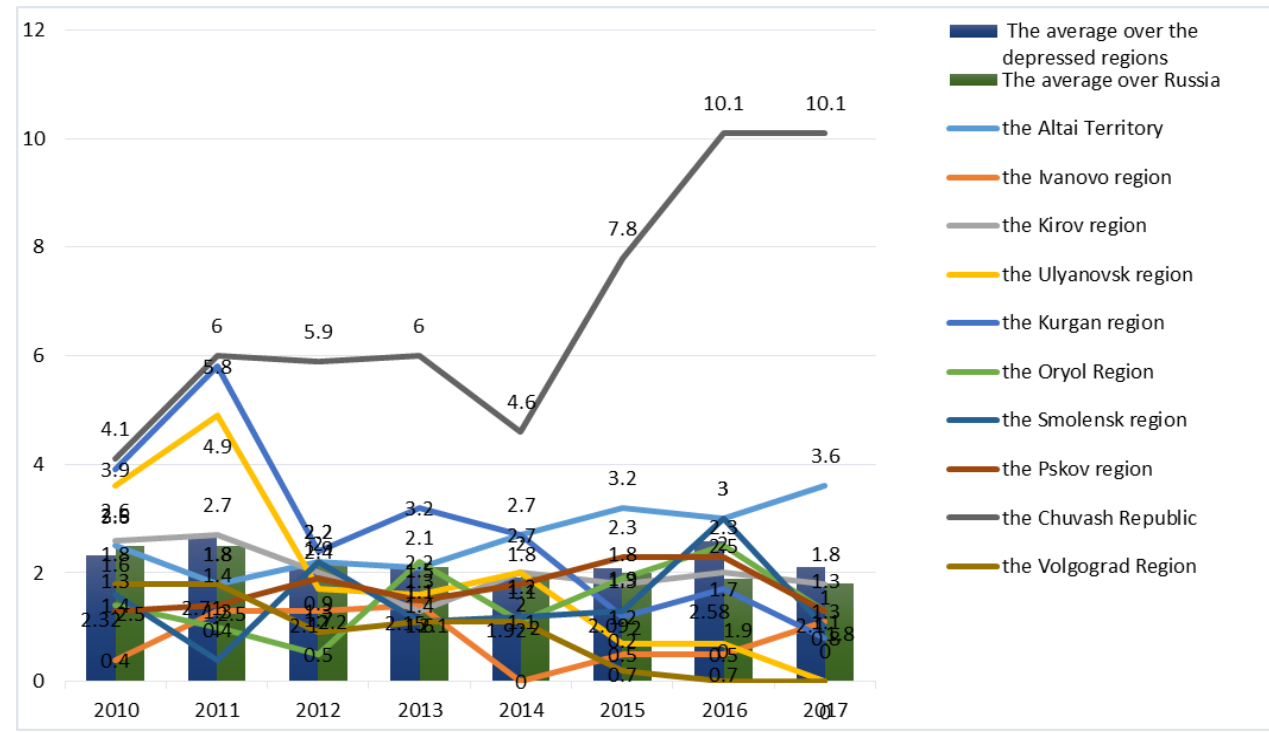

Fig. 6. The proportion of organizations implementing marketing innovations in the total number of organizations (in industrial production, in percent) (Data source: Rosstat, HSE).

Another area of the analysis of the state and trends in the development of the innovative activity is the results of the rating of innovative regions of Russia by the Association of Innovative Regions of Russia (AIRR). The rating distinguishes 5 groups of regions according to the level of innovation development: strong innovators (SI), average-strong innovators (A-SI), average innovators (AI), average-weak innovators (A-WI), weak innovators (WI). Table 1 shows the distribution of the depressed regions from 2014 to 2018 according to the AIRR rating.

Table 1. Rating of innovative regions of Russia (Data source: AIRR).

\begin{tabular}{|c|c|c|c|c|c|}
\hline Region & 2014 & 2015 & 2016 & 2017 & 2018 \\
\hline the Altai Territory & AI & AI & A-SI & AI & AI \\
\hline the Ivanovo region & A-SI & AI & AI & AI & AI \\
\hline the Kirov region & AI & AI & AI & AI & AI \\
\hline the Ulyanovsk region & A-SI & A-SI & A-SI & SI & A-SI \\
\hline the Kurgan region & AI & A-WI & A-WI & A-WI & AI \\
\hline the Oryol region & AI & AI & A-WI & AI & AI \\
\hline the Smolensk region & AI & AI & AI & AI & AI \\
\hline the Pskov region & A-WI & A-WI & A-WI & A-WI & A-WI \\
\hline the Chuvash Republic & A-SI & A-SI & A-SI & A-SI & A-SI \\
\hline the Volgograd Region & AI & AI & A-WI & AI & AI \\
\hline
\end{tabular}


The highest places among the depressed regions in this rating belong to two regions - the Chuvash Republic and the Ulyanovsk Region, which are identified as average-strong innovators. The lowest place belongs to the Pskov region, which from 2014 to 2018 was an average-weak innovator. In general, the majority of the depressed regions (from 60 to $70 \%$ ) in this rating are average innovators. The analysis of the positions of the depressed regions in the AIRR rating suggests that in the medium term, the following regions will be the most innovatively active: the Ulyanovsk Region, the Chuvash Republic, and possibly the Altai Territory.

Considering the high places of the Ulyanovsk Region and the Chuvash Republic among all depressed regions in the AIRR rating, it is recommended to consider these regions as benchmarks for benchmarking innovation activity of organizations and the innovative development of their economy in general in all depressed regions.

\section{Discussion}

Summarizing the results of the analysis of the state of the innovative activity in the depressed regions, we can draw a general conclusion about the insufficiency of its development. Most depressed regions are characterized by a low level of the innovative activity of organizations, an insignificant volume of production of innovative products and costs of technological innovation, which is a common feature for these regions. A feature of the development of the innovative activity in these regions is: the differentiated dynamics of the indicators of the innovation activity, a significant gap in the values of indicators of the innovation activity among the regions, the popularity of marketing innovations in the regions, which may indicate a different level of the innovative potential, insufficient degree of coordination and sequence of actions of participants in regional innovation systems focusing on the production of traditional products and providing sales through innovative marketing techniques. Most depressed regions occupy average positions in the ranking of innovative development of Russian regions.

Considering the foregoing, a promising direction for the development of the innovative activity in the depressed regions, in our opinion, is the creation and launch of innovation clusters on their territory.

Development of the cluster approach in the depressed regions will make it possible to actively attract foreign investment and intensify the production of highly competitive innovative products. This is confirmed by the results of studies of already established and functioning innovative territorial clusters [18]. As a result of the work of innovative territorial clusters, there is a positive dynamics of such basic indicators of innovative and socio-economic development of the regions as: the volume of innovative goods, works, services; fixed investment per capita; the volume of gross regional product per one resident of the region [18].

The clustering process should take into account both the successful experience of creating such clusters in other regions and the strong points of each particular region, which may in the future become the basis of development of their sustainable competitive advantages. Such strong points include: advantageous geographical position; the presence of unique natural resources; human potential, etc.

\section{Conclusions}

The study allowed us to analyze and evaluate the state of the innovative activity in the depressed regions, to identify emerging trends and features of their innovative development. The results make it possible to better understand and predict the 
consequences of managerial decisions at various levels of government in stimulating and supporting innovative processes in such regions, and in developing adequate innovative strategies and programs.

Prospects for the further research are seen in the economic and statistical analysis of factors of innovative development of the depressed regions to establish the presence, strength and direction of the influence of each of them on the state and effectiveness of the innovative activity in the regions and to develop adequate measures on this basis, as well as to establish the correlation between indicators of the innovative activity and indicators of the socio-economic development of the depressed regions, which will determine strategically significant directions of the development of innovations for these regions and get their economies out of the state of depression.

\section{References}

1. R. Boschma, J. Lambooy, GeoJournal, 391 (1999)

2. A. Cumbers, K. Birch, Divergent Pathways in Europe's Old Industrial Regions? (Center for Public Policy for Regions (CPPR), 2006)

3. R. Hassink, D. Shin, Environment and Planning (2005)

4. B. Iking, Promoting industrial change in structurally disfavoured regions. The case of the "Ruhr Valley" in Germany. International Symposium for Industrial Regeneration of Korea, Germany and Japan (2004)

5. R. McGahey, J. Vey, Retooling for growth: Building a 21 st Century Economy in America's Older Industrial Areas (Washington, DC, USA: Brookings Institution Press, 2008)

6. M. Steiner, Old Industrial Areas: A theoretical Approach. Urban Studies (1985)

7. L. Tsipouri, Can less favored regions change their destiny? Lessons from Europe (Springer, 2004)

8. S.A. Surkova, V.V. Shusharina, Depressive regions: typological features and mechanisms for overcoming depression. Regional Economics: Theory and Practice (2009)

9. A.G. Granberg, Fundamentals of the regional economy (Moscow, GU VSHE, 2003)

10. B.M. Shtulberg, About depressed territories in the Russian Federation. Ways to overcome the crisis: materials for the Parliament hearings (Moscow, SOPS, 1997)

11. V.Ye. Seliverstov, M.K. Bandman, S.S. Guzner, Region: Economics and Sociology 3 (1996)

12. N.V. Yakovenko, Depressed regions of Russia: methodology, theory, applied aspects: on the example of the Ivanovo region (Voronezh, Voronezhskiy gos. Universitet, 2013)

13. O.V. Asmus, The development of the agricultural sector in the depressed regions of the Russian Federation: theory, methodology, practice (Moscow, all-Russian research institute of economy of agriculture of Russian Academy of Agricultural Sciences, 2008)

14. N.A. Sankovets, Economic development of Russian regions: differentiation and regulation (Ulan-Ude, East-Sib. state technol. and management, 2011)

15. N.Y. Adyugizelova, Characteristics of regional depression in the market economy (RPPE, 2011)

16. V. Holodkova, A. Mottaeva, T. Pokrovskaya, E3S Web of Conferences 164, 11043 (2020) https://doi.org/10.1051/e3sconf /202016411043 
17. K.A. Chernyshev, The study of constant migration of population of depressed regions of Russia. Ekonomicheskiye I Sotsial'nyye Peremeny: Fakty, Tendentsii, Prognoz (2017)

18. N.A. Tyuleneva, Yu.S. Pupina, D.A. Zhavrina, A.A. Shcherbinina, L.A. Makarova, Vestnik Tomskogo Gosudarstvennogo Universiteta. Ekonomika, 76 (2020)

19. Regions of Russia. Socio-economic indicators (Moscow, Rosstat, 2019)

20. Indicators of the innovative activity: 2019 (Moscow, HSE,2019)

21. Indicators of the innovative activity: 2018 (Moscow, HSE, 2018)

22. Indicators of the innovative activity: 2016 (Moscow, HSE, 2016)

23. Indicators of the innovative activity: 2015 (Moscow, HSE, 2015)

24. Indicators of the innovative activity: 2014 (Moscow, HSE, 2014)

25. Indicators of the innovative activity: 2013 (Moscow, HSE, 2013)

26. Rating of the innovative regions of Russia (Moscow, AIRR, 2018)

27. Rating of the innovative regions of Russia (Moscow, AIRR, 2014)

28. Rating of the innovative regions of Russia (Moscow, AIRR, 2015)

29. Rating of the innovative regions of Russia (Moscow, AIRR, 2016)

30. Rating of the innovative regions of Russia (Moscow, AIRR, 2017) 